\title{
Differential Diagnosis of Thyroid Dermopathy and Acropachy with Arthritis
}

\author{
Tiroid Dermopati ve Akropaçisinin Artritlerle Ayııı ı Tanısı \\ (1) Nurdan Yılmaz, (1) Pelin Gümüş Ok \\ Tokat Gaziosmanpaşa University Faculty of Medicine, Department of Physical Medicine and Rehabilitation, Tokat, Turkey
}

\section{Abstract}

Thyroid acropachy is a rare manifestation of autoimmune thyroid disease with characteristic imaging findings. Clinically, it is almost always associated with thyroid ophthalmopathy and dermopathy. It presents as nail clubbing and swelling of the digits and toes. Especially, symmetrical swelling of the hands and feet as well as clubbing of the nails may require differential diagnosis with many hepatic, pulmonary, renal and even rheumatologic diseases. Radiologically, soft-tissue swelling and periosteal new bone formations are particularly significant. We present a 22-year-old female with Graves' disease who presented with bilateral swelling of the hands and feet and was diagnosed with thyroid acropachy following clinical and radiological evaluations.

Keywords: Graves' disease, thyroid, acropachy, dermopathy, ophthalmopathy

\section{$\ddot{O z}$}

Tiroid akropaçisi, karakteristik görüntüleme bulgularının gözlendiği nadir otoimmün tiroid hastalığının nadir bir tezahürüdür. Klinik olarak, neredeyse her zaman tiroid oftalmopati ve dermopatisi ile ilişkilidir. Tırnaklarda çomaklaşma ve el ve ayak parmaklarında şişlikler şeklinde görülür. Özellikle ellerin ve ayakların simetrik şişmesi ve tırnakların çomaklaşması birçok hepatik, pulmoner, renal ve hatta romatolojik hastalıkla ayırıcı tanı gerektirebilir. Radyolojik olarak yumuşak doku şişmesi ve periosteal yeni kemik oluşumları özellikle önemlidir. Burada, el ve ayaklarda bilateral şişlik ile başvuran ve klinik ve radyolojik değerlendirmelerle tiroid akropaçisi tanısı alan 22 yaşında Graves tanılı bir kadın hasta sunuldu. Anahtar kelimeler: Graves hastalığı, tiroid, akropaçi, dermopati, oftalmopati

\section{Introduction}

Thyroid acropachy is an extrathyroidal clinical manifestation of autoimmunity that affects less than $1 \%$ of the patients with Graves' disease (GD) and can be seen in euthyroid or hypothyroid patients within weeks and years after treatment for thyrotoxicosis (1). It is more common in females and the peak age range is $50 \mathrm{~s}(2,3)$. The clinical feature of thyroid acropachy is that it is usually symmetrical and bilateral (4). In thyroid acropachy, nail clubbing caused by glycosaminoglycan accumulation, proliferation in the diaphysis and hypertrophy of the surrounding soft tissues are observed (1). It is almost always associated with thyroid ophthalmopathy and dermopathy (5). We present a 22-year-old female patient with a history of total thyroidectomy due to GD in an euthyroid status after operation with the complaint of diffuse swelling and pain of the hands and feet; diagnosed as thyroid ophthalmopathy, dermopathy and acropachy after clinical and radiological evaluations.

\section{Case Report}

A 22-year-old female patient was referred to our outpatient clinic with a prediagnosis of arthritis due to swelling of both hands and feet, especially bulking of bilateral dorsum of the feet. The patient also complained of range of motion limitation and pain. The patient had these complaints for the last two years but showed a progressive deterioration especially in the last one year. There was no change in temperature or skin color of the joints. There was no trauma history. However, the patient's anamnesis revealed that she had been received anti-thyroid drug treatment for a while with the diagnosis of GD before total thyroidectomy; however, total thyroidectomy was performed because there was no clinical and laboratory improvement; and she had been receiving levothyroxine sodium $100 \mathrm{mcg} /$ day after the operation. The physical examination demonstrated bilateral eyelid retraction compatible with thyroid ophthalmopathy and significant myxedematous changes to the

Address for Correspondence/Yazışma Adresi: Nurdan Yılmaz Ass. Prof., Tokat Gaziosmanpaşa University Faculty of Medicine, Department of Physical Medicine and Rehabilitation, Tokat, Turkey

Phone: +90 3562129500 E-mail: nurdanyilmazdr@hotmail.com ORCID ID: orcid.org/0000-0001-5758-6792

Received/Geliş Tarihi: 03.04.2020 Accepted/Kabul Tarihi: 13.07.2020

${ }^{\circ}$ Copyright 2021 by the Turkish Osteoporosis Society / Turkish Journal of Osteoporosis published by Galenos Publishing House 
bilateral hands, fingers, ankles, especially in the dorsum of the both feet (Figure 1, 2). The patient had no physical examination findings suggesting arthritis, but described pain in bilateral hands and feet. There were signs of nail clubbing of the hands (Figure 2). Hepatic and renal functions and blood electrolytes were found to be normal in the laboratory evaluation. Serological tests for rheumatologic diseases were negative. Erythrocyte

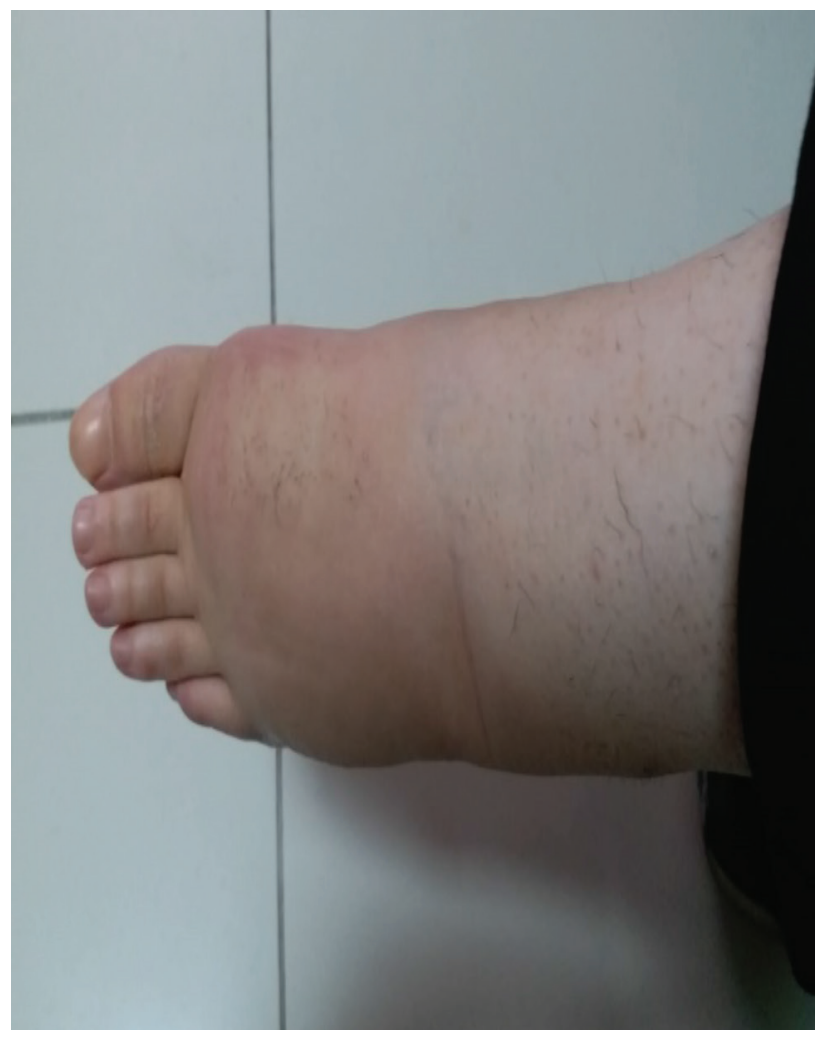

Figure 1. Swelling in the dorsum of the foot consistent with myxedema involving the ankle (left foot)

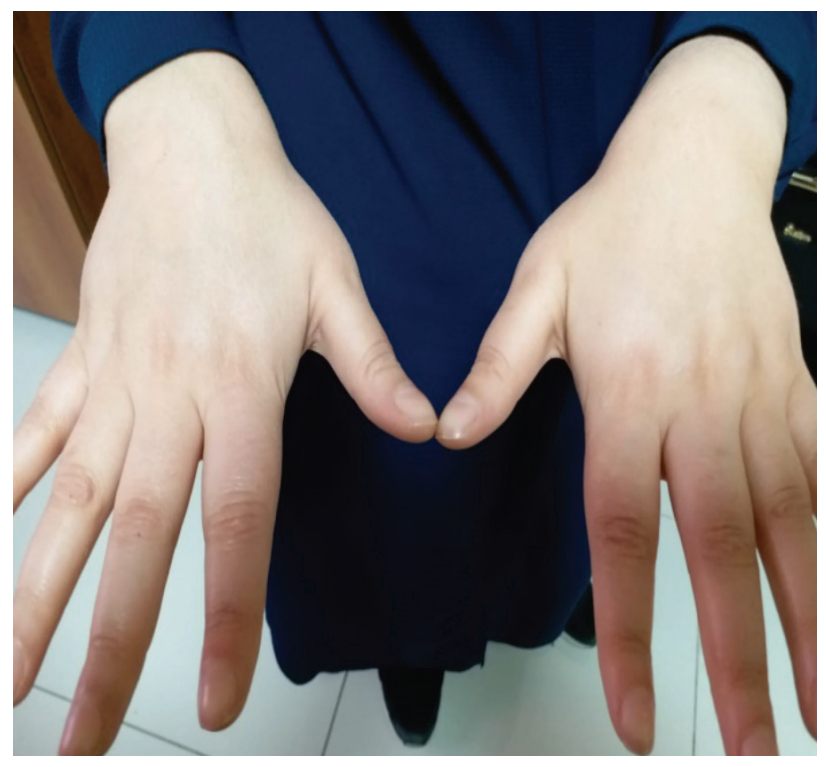

Figure 2. Swelling and nail clubbing in both hands extending up to the level of the proximal interphalengeal joint sedimentation rate and C-reactive protein values were within normal limits. Serum thyroid stimulating hormone (TSH) level was $0.874 \mathrm{mIU} / \mathrm{L}(\mathrm{N}: 0.3-4.5 \mathrm{mIU} / \mathrm{L})$ and serum free T4 level was $1.29 \mathrm{ng} / \mathrm{dL}(\mathrm{N}$ : 0.8-1.8 ng/dL). Direct X-ray imaging of the feet demonstrated bilateral soft tissue swelling (Figure 3 ). In addition, periosteal new bone formations were present in the $1^{\text {st }}$ and $5^{\text {th }}$ metatarsals of the right foot (Figure 4). Magnetic resonance imaging was performed for both feet. Muscle planes and tendons that entered the plane of bilateral examination had normal signal characteristics. There was significant edema

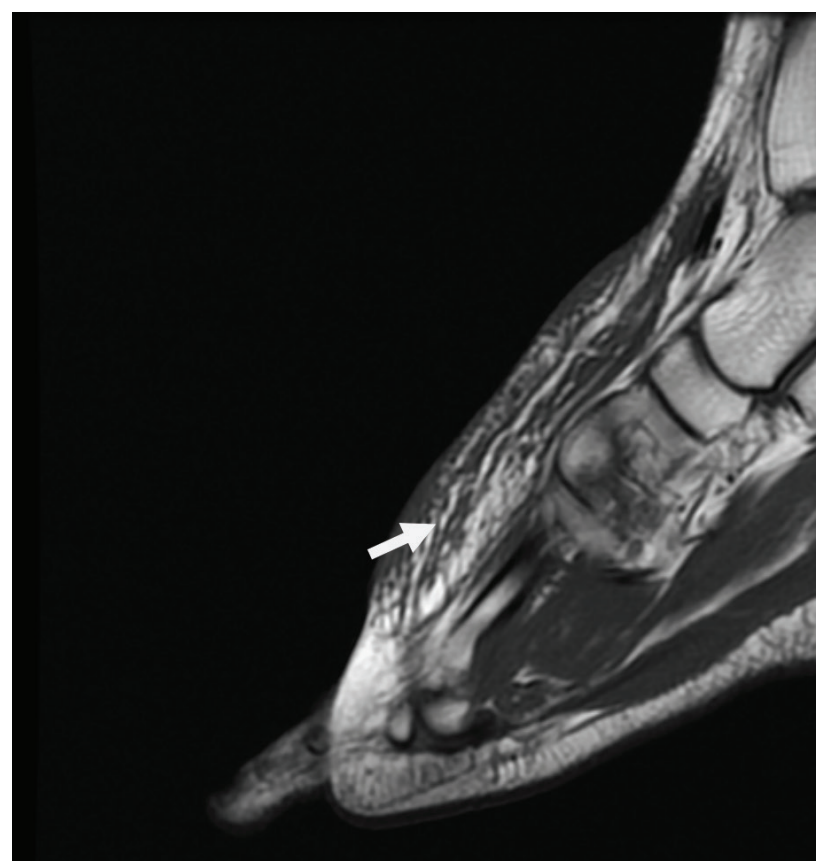

Figure 3. Increased thickness and edema of the dorsum of the foot on T1-weighted magnetic resonance imaging of the right foot (white arrow)

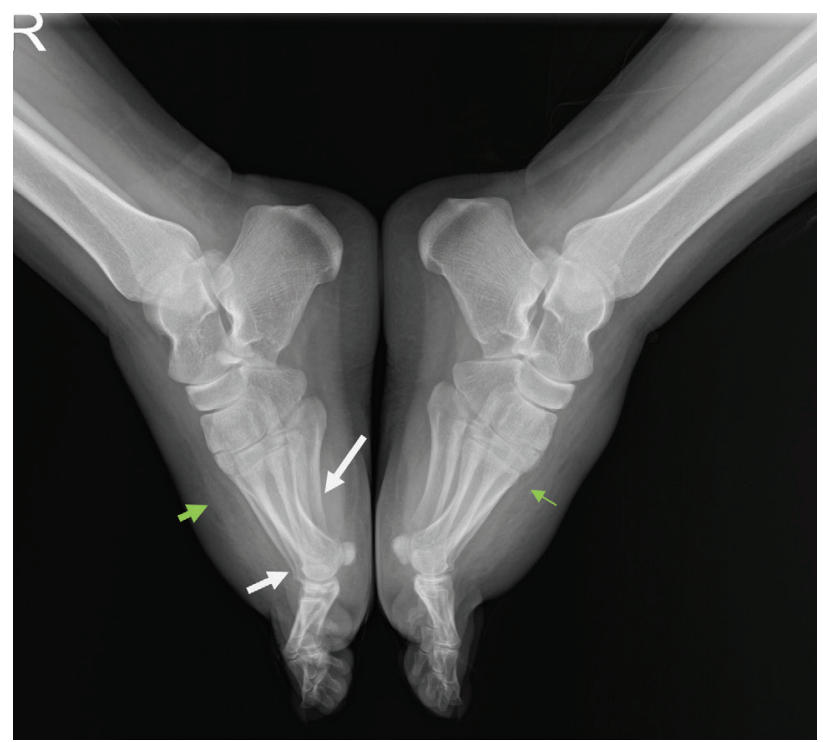

Figure 4. White arrows indicate periosteal new bone formation in the $1^{\text {st }}$ and $5^{\text {th }}$ metatarsal bones. Green arrows indicate soft tissue edema in the dorsum of both feet 
and thickening of the bilateral foot dorsals. These findings were consistent with thyroid dermopathy and associated thyroid acropachy. The patient was followed by the ophthalmology clinic for thyroid ophthalmopathy. The patient was consulted with the dermatology clinic for thyroid dermopathy and acropachy. The patient was informed about regular follow-up visits to endocrinology clinic in terms of thyroid dysfunction, and non-steroidal anti-inflammatory agents (NSAIDs) could be used for pain complaints, also pentoxifylline $600 \mathrm{mg} \mathrm{2*1}$ treatment was initiated. The patient with a smoking history of 3 packs/year was recommended to quit smoking. In addition, our patient was informed about the case presentation and informed consent was obtained.

\section{Discussion}

Thyroid acropachy is the least seen extrathyroidal manifestation of autoimmune thyroid diseases (1). Graves' acropachy was first reported in a female patient with GD who was treated with thyroidectomy in 1933 (6). The coexistence of the triad of ophthalmopathy, dermopathy and acropachy in GD is very rare and occurs only in 0.8 to $1 \%$ of the patients with Graves ophthalmopathy $(3,5)$. Graves acropachy is strongly associated with severe Graves ophthalmopathy and dermopathy and almost all cases occur simultaneously with ophthalmopathy and dermopathy (5). In fact, the chronological sequence of the extrathyroidal manifestations of autoimmune thyroid disease is that first thyroid dysfunction, next ophthalmopathy, then dermopathy, and finally acropachy are revealed (5). Most patients have nail clubbing and periosteal reactions in the phalanges. Lower extremity pain, skin and nail changes may indicate acropachy (5). Although the exact etiology is not known, autoantibodies against TSH and insulin like growth factor-1 receptors are thought to be involved in the pathophysiology of thyrotoxicosis and ophthalmopathy in $\operatorname{GD}(7,8)$. It is thought that TSH receptor autoantibodies bind to TSH receptors of the fibroblasts in the periosteum and trigger inflammatory response by increased cell proliferation and accumulation of glycosaminoglycans $(5,9)$. Some studies have shown that smoking is a predisposing factor for acropachy in patients with GD (10-12). In our case, the ophthalmopathy, dermopathy and acropachy trio were present together and our patient had a history of smoking. In this respect, it is thought that smoking may play a role in the progression of the complaints of our patient despite being euthyroid as laboratory.

Acropachy is usually asymptomatic, but the main clinical symptoms may include nail clubbing, pain in small joints, soft tissue swelling, reactive changes in the periosteum, and changes in the skin and nails of the fingers (5). This disorder mostly involves the metacarpophalangeal and proximal interphalangeal joints of the upper extremity; in the lower extremity, it especially involves the ankles and the metatarsophalangeal joints (13). There is no temperature increase in soft tissue edema and is often associated with bone changes (13). Acropachy is extremely rare before the onset of thyrotoxicosis, 95\% of the patients with acropachy develop the disease during GD treatment (14). In patients with clubbing of the fingers, the diagnosis is based on only the clinical findings (5). Histological examination shows that there is nodular fibrosis in the distal periosteum (13). Similarly, our patient's complaints were revealed when she was being treated for GD and our patient described pain especially on her hands.

There is no specific treatment for acropachy, high potency corticosteroids have been used and some patients have been successfully treated with rituximab $(14,15)$. Patients with joint pain can be treated with NSAIDs such as ketoprofen (14). It is known that pentoxifylline intradermal, intravenous and oral use regresses dermatological symptoms in the treatment of pretibial myxedema $(16,17)$. Treatment of thyrotoxicosis may lead to an improvement in the clinical manifestations of acropachy, but the role of thyroid function control in acropachy is uncertain $(5,14)$. Despite the fact that our case is euthyroid, the progression of her complaints is consistent with the literature suggesting that the role of thyroid function control in acropachy is uncertain. Although the primary treatment of our patient is planned to maintain the euthyroid status and to use oral pentoxifylline in addition to NSAIDs for joint pain, at controls further treatment options will be evaluated according to the clinical status of our patient.

Acropachy is a rare presentation of thyroid autoimmunity. Corticosteroids, NSAIDs, pentoxifylline and in some cases rituximab may be good treatment alternatives. To provide and maintain euthyroidism is one of the main objectives; however the clinical benefit of euthyroidism in acropachy is unclear. Thyroid acropachy is a relatively benign condition that is usually asymptomatic. Clinical recognition of this condition is very important, because clubbing and swelling of the extremities may cause unnecessary research for many pulmonary, cardiac, hepatic or rheumatologic diseases.

\section{Ethics}

Informed Consent: Written informed consent was obtained from the patient prior to the drafting of the manuscript.

Peer-review: Externally and internally peer-reviewed.

\section{Authorship Contributions}

Surgical and Medical Practices: N.Y., P.G.O., Concept: N.Y., P.G.O., Design: N.Y., P.G.O., Data Collection or Processing: N.Y., P.G.O., Analysis or Interpretation: N.Y., P.G.O., Literature Search: N.Y.,P.G.O., Writing: N.Y., P.G.O.

Conflict of Interest: No conflict of interest was declared by the authors.

Financial Disclosure: The authors declared that this study received no financial support.

\section{References}

1. Anderson CK, Miller OF 3rd. Triad of exophthalmos, pretibial myxedema, and acropachy in a patient with Graves' disease. J Am Acad Dermatol 2003;48:970-2. 
2. Vanhoenacker FM, Pelckmans MC, De Beuckeleer LH, Colpaert CG De Schepper AM. Thyroid acropachy: correlation of imaging and pathology. Eur Radiol 2001;11:1058-62.

3. Jadidi J, Sigari M, Efendizade A, Grigorian A, Lehto SA, Kolla S. Thyroid acropachy: A rare skeletal manifestation of autoimmune thyroid disease. Radiol Case Rep 2019;14:917-9.

4. Neves C, Alves M, Delgado JL, Medina JL. Doença de Graves. Arq Med 2008;22:137-46.

5. Fatourechi $\mathrm{V}$, Ahmed DD, Schwartz KM. Thyroid acropachy: report of 40 patients treated at a single institution in a 26-year period. J Clin Endocrinol Metab 2002;87:5435-41.

6. Thomas HM. Acropachy, or Secondary Subperiosteal New-Bone Formation. Trans Am Climatol Clin Assoc 1932;48:208-28.

7. Fatourechi V. Thyroid dermopathy and acropachy. Best Pract Res Clin Endocrinol Metab 2012;26:553-65.

8. Wiersinga WM. Autoimmunity in Graves' ophthalmopathy: the result of an unfortunate marriage between TSH receptors and IGF1 receptors? J Clin Endocrinol Metab 2011;96:2386-94.

9. Jameson JL, De Groot L. Graves' Disease. In: Jamerson JL, De Groot L, de Krester DM, Giudice LC, Grossman AB, Melmed S, et al, editors. Endocrinology: Adult and Pediatric. 7th ed. Philadelphia PA: Elsevier Saunders; 2015. p. 1451- 3.

10. Anwar S, Gibofsky A. Musculoskeletal manifestations of thyroid disease. Rheum Dis Clin North Am 2010;36:637-46.
11. Thornton J, Kelly SP, Harrison RA, Edwards R. Cigarette smoking and thyroid eye disease: a systematic review. Eye (Lond) 2007;21:1135-45.

12. Gruppen EG, Kootstra-Ros J, Kobold AM, Connelly MA, Touw D, Bos JHJ, et al. Cigarette smoking is associated with higher thyroid hormone and lower TSH levels: the PREVEND study. Endocrine 2020;67:613-22.

13. Bland JH, Frymoyer JW, Newberg AH, Revers R, Norman RJ. Rheumatic syndromes in endocrine disease. Semin Arthritis Rheum 1979:9:23-65.

14. Bartalena L, Fatourechi V. Extrathyroidal manifestations of Graves' disease: a 2014 update. J Endocrinol Invest 2014;37:691-700.

15. Ferreira-Hermosillo A, Casados-V R, Paúl-Gaytán P, Mendoza-Zubieta V. Utility of rituximab treatment for exophthalmos, myxedema, and osteoarthropathy syndrome resistant to corticosteroids due to Graves' disease: a case report. J Med Case Rep 2018;12:38.

16. Türke B, Balázs C. Treatment of pretibial myxoedema with pentoxifylline. Orv Hetil 2012;153:1719-22.

17. Finamor FE, Martins JR, Nakanami D, Paiva ER, Manso PG, Furlanetto RP. Pentoxifylline (PTX)-an alternative treatment in Graves' ophthalmopathy (inactive phase): assessment by a disease specific quality of life questionnaire and by exophthalmometry in a prospective randomized trial. Eur J Ophthalmol 2004;14:277-83. 